\title{
KSIĘGA JOZUEGO W SEPTUAGINCIE
}

Stało się tradycją, że w trakcie sympozjów zatytułowanych „Interpretacja Pisma Swiętego", organizowanych w Uniwersytecie Kardynała Stefana Wyszyńskiego w Warszawie i dotyczących poszczególnych ksiąg Starego Testamentu, rozważa się tematy związane z Septuagintą. ${ }^{1}$ Grecka tradycja Starego Testamentu jest ważna nie tylko dlatego, że stanowi cenne źródło informacji o możliwościach przekładu tekstu hebrajskiego (i to w najstarszym posiadanym przez nas thumaczeniu), ale także dlatego, że daje wgląd w tendencje interpretacyjne poszczególnych ksiąg świętych w starożytności, ukazując rozwój myśli teologicznej i wiary żydowskiej w czasach przedchrześcijańskich. Do tego jeszcze, w przypadku niektórych ksiąg - a tak jest, jak się wydaje, z Księgą Jozuego - tekst LXX może stanowić źródło dotarcia do najstarszych tradycji tekstualnych Biblii - starszych nawet niż posiadany przez nas tekst hebrajski. Należy pamiętać, że o ile świadectwa masoreckiego tekstu Biblii Hebrajskiej pochodzą z początku XI w., o tyle zachowane świadectwa Septuaginty są o kilkaset lat starsze. Pod koniec ery przedchrześcijańskiej Septuaginta była Biblią judaizmu hellenistycznego przyjętą i popularną wśród Żydów mówiących po grecku.

1 Temat Septuaginty podejmowany na tegorocznym Sympozjum, które odbyło się $20 \mathrm{~V}$ 2014 r., nabrał szczególnego znaczenia w kontekście śmierci pierwszego w dziejach Polski tłumacza LXX na nasz język, ks. prof. Remigiusza Popowskiego SDB, który zmarł kilka dni wcześniej, 15 V 2014 r., pozostawiwszy po sobie przekład całej Biblii Greckiej (Starego i Nowego Testamentu) na język polski: R. P o p o w s k i (tłum., wprowadzenie i przypisy), Septuaginta, czyli Grecka Biblia Starego Testamentu z księgami deuterokanonicznymi, apokryfami żydowskimi oraz onomastykonem, Prymasowska Seria Biblijna 41, Warszawa 2014 oraz przekład sprzed kilku lat, wznowiony i poprawiony niedawno: R. P o p o w s k i, M. W o j c i e c h o ws k i (tłum.), Grecko-polski Nowy Testament. Wydanie interlinearne z kluczem gramatycznym. $z$ kodami Stronga i Popowskiego oraz petnq transliteracją greckiego tekstu, Prymasowska Seria Biblijna 40, Warszawa 2014. 


\section{Datacja pierwotnego przekladu greckiego Joz (Old Greek) ${ }^{2}$}

Księga Jozuego jest niezwykle ważna w tradycji biblijnego Izraela, ponieważ mówi o początkach narodu wybranego w swojej ziemi (o zajmowaniu i zasiedlaniu ziemi Kanaan). Jest także ważna, ponieważ następuje bezpośrednio po Torze, kontynuując ją w wielu wymiarach: w tym, co dotyczy treści, a także teologii i przesłania. Talmud mówił nawet, że „gdyby Izrael nie grzeszył, dane by mu były jedynie księgi Tory wraz z Księgą Jozuego" (traktat Nedarim 22b) ${ }^{3}$ i wystarczyłoby to, by ukazać istotę wiary i tożsamości narodu. Joz jest zatem częścią najważniejszej spuścizny narodu żydowskiego. Zapewne z tego powodu dość szybko księga doczekała się przekładu na język grecki. Jej pierwsze greckie tłumaczenie powstało najprawdopodobniej już w drugiej połowie III w przed Chr., ${ }^{4}$ u początków przekładów LXX.

Choć nie ma wielu argumentów poświadczających tę tezę, w ustaleniu takiej daty powstania LXXJoz wskazuje się przede wszystkim na bliskość daty przekładu Pięcioksięgu (którą źródła starożytne, m.in. List PseudoArysteasza, a także współczesne badania, sytuują w czasach panowania Ptolemeusza II Filadelfa, czyli w pierwszej połowie III w. przed $\mathrm{Chr}^{5}$ ). Ponieważ Księga Jozuego w kanonie następuje bezpośrednio po Pięcioksięgu i stanowi - jak zostało wspomniane - część tej samej ważnej spuścizny, przypuszcza się, że jej przekład grecki musiał powstać także niedługo po greckim tłumaczeniu Pięcioksięgu.

2 W artykule używa się skrótu LXXJoz na określenie greckiego przekladu Księgi Jozuego. Jeśli nie zaznaczono inczej, tekstem LXXJoz, do którego artykuł się odnosi, jest Kodeks Watykański (B), na którym oparte jest w większości wydanie krytyczne: A. R a h I f s, Septuaginta, Id est Vetus Testamentum Graece iuxta LXX interpretes, Stuttgart 1935, $1965^{8}$.

3 Zob. angielski przeklad tego Traktatu: J. N e u s n e r, The Babylonian Talmud, t. 10: Tractate Nedarim; Tractate Nazir: a Translation and Commentary, Peabody MA 2005; por. także: J. M o a t $t$ i - F i n e, La Bible d'Alexandrie. 6: Jésous (Josue). Traduction du texte grec de la Septante, Introduction et notes, Paris 1996, s. 21.

4 Por. L.J. G r e e n s p o o n, lesous. To the Reader, w: A. P i e t e r s m a, B.G. W rig h t (red.), A New English Translation of the Septuagint. And the Other Greek Translations Traditionally Included under that Title, NETS, Oxford University Press, New York-Oxford 2007, s. 174.

s Na temat datacji przekładu według apokryfu i według współczesnych badań por. krótkie podsumowanie w: B. S t r z a ł k o w s k a, Księga Rodzaju w Septuagincie, Biblica et Patristica Thoruniensia 4/2011, s. 95-121 (Sum.); oraz t a ż, Księga Kaplańska w Septuagincie, Collectanea Theologica $80(2010) \mathrm{nr} 4$, s. 67-84. 
Świadczą o tym obecne w niej nawiązania do greckiego Pentateuchu. Choćby w użyciu niektórych terminów, analogicznie do Pięcio-

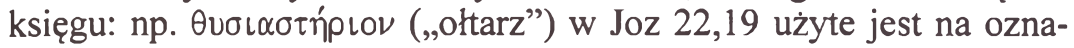
czenie „legalnego” ołtarza (odróżniającego się od fałszywego, na który wskazuje tekst, używając terminu $\beta \omega \mu$ ó $)$, tak jak w tekście Tory. ${ }^{6}$ J. Moatti-Fine, autorka jedynego istniejącego komentarza do LXXJoz (w serii „La Bible d'Alexandrie”), nazywa nawiązania terminologiczne LXXJoz do Pięcioksięgu (zwłaszcza w tym, co dotyczy polityki i kwestii religijnych) une fidélité intelligente (,inteligentną wiernością"). ${ }^{7}$ Charakter przekładu w LXXJoz przypomina poniekąd ten stosowany przez thumaczy Pięcioksięgu, choć w Księdze Jozuego daje się poznać dużo większą swobodę i wolność (por. część dotyczącą charakteru przekładu poniżej).

Skoro wiadomo, że przekład LXXJoz powstał po Pięcioksięgu, pozostaje zbadać, kiedy dokładnie. Pomocne w ustaleniu datacji przekładu mogłoby być nawiązanie do postaci Jozuego w Księdze Syracydesa, która w drugiej połowie II w. przed Chr. (nie mamy co do tej datacji wątpliwości) wspomina Jozuego w sposób, który każe zastanowić się, czy jej autor nie miał już przed oczami greckiego przekładu tej księgi. Swiadczyć by o tym mogło oryginalne użycie imie-

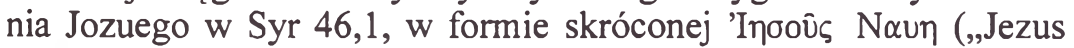
[syn] Nuna"), a nie, jak w większości w Torze, w pełnej formie 'Inoõ û́ víòs Naun („Jezus syn Nuna”). Sama grecka Księga Jozuego używa wprawdzie obu form (i pełnej, i skróconej), choć tej drugiej uży-

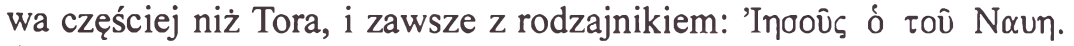
Argument ten wydaje się więc zbyt słaby. Ponadto grecki Pentateuch takiego skróconego wyrażenia także używa (choć rzadko: np. w: Lb $11,28 ; 14,6.30 .65 ; 32,12 ; 34,17$ czy w Pwt 32,44$).{ }^{8}$ To jedyne zdanie o Jozuem z Księgi Syracydesa daje poznać, że dokonania Jozuego były autorowitej księgi znane, a sam Jozue określony jest jako ten,

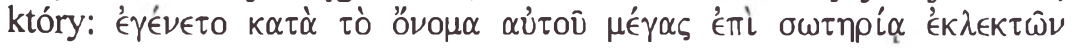

6 L.J. G r e e n s p o o n, Iesous. To the Reader, s. 174; por. także C.G. d e n H e r t o g, Jesus. Josue/ Das Buch Josua, w: M. K a r r e r, W. K r a u s i in. (red.), Septuaginta Deutsch. Erläuterungen und Kommentare zum griechischen Alten Testament, t. I: Genesis bis Makkabäer, Deutsche Bibelgesellschaft, Stuttgart 2011, s. 607--608.

7 Por. J. M o a t t i - F i n e, La Bible d'Alexandrie. 6: Jésous (Josué), s. 42 (i szczególowe omówienie s. 42-53).

8 Na temat imienia Jozue i jego form greckich zob. tamże, s. 42; a takze J.A. S o g g i n, Le livre de Josué, Commentaire de l'Ancien Testament Va, Neuchẩtel 1970, s. 9 (uważal on użytą w Syr formę imienia i pochodzenia Jozuego za pierwotną). 


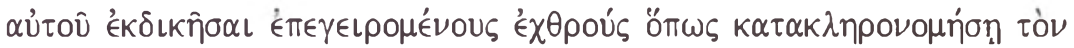
I $\sigma \alpha \eta \lambda$ (,stał się, stosownie do swego imienia, wielkim przez to, że ocalił Jego wybranych, że wywarł pomstę na opornych wrogach, by wprowadzić Izraela w jego dziedzictwo"). Syr 46,1 ukazuje go jako

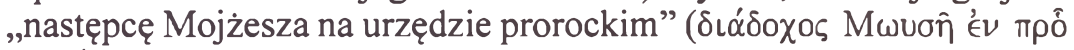
$\phi \eta \tau \in \dot{L} \alpha \iota \varsigma)$, co jest typowym greckim wyrażeniem, wskazującym jednak bardziej na charakter Księgi Syracydesa niż na charakter ewentualnego przekładu Księgi Jozuego.

Analizując tekst Księgi Jozuego w LXX, C.G. den Hertog zwraca uwagę, że w LXXJoz kompletnie brakuje aluzji do trudności, które przeżywał naród żydowski w czasie prześladowań za panowania Antiocha IV Epifanesa, czy nawiązań sugerujących, że autor przekładu znał wydarzenia $\mathrm{z}$ powstania machabejskiego. ${ }^{9} \mathrm{Z}$ drugiej strony, tematyka zdobywania i zasiedlania ziemi Kanaan, którą podejmuje Księga Jozuego, mogłaby stać się inspiracją i impulsem do przełożenia jej na język grecki właśnie w momencie tych niełatwych wydarzeń z połowy II w. przed Chr.

C.G. den Hertog za ważne i pomocne w ustaleniu datacji greckiego przekładu Księgi Jozuego uznaje nazwy geograficzne, tak licznie (choć niekonsekwentnie!) reprezentowane w LXXJoz. ${ }^{10}$ Można w niej znaleźć charakterystyczne dla administracji ptolemejskiej na-

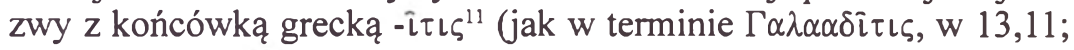

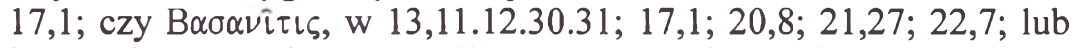
interesujący termin: M $\alpha \delta \beta \alpha \rho i \tau \iota \varsigma$, nazwa własna, która występuje w Joz 5,6, gdzie przekłada hebr. מִרְבר, to znaczy „pustynia”; por. także tę nazwę w 18,2; 15,61). Badacz zaznacza, że z tych trzech terminów tylko $\Gamma \alpha \lambda \alpha \alpha \delta i \tau \iota \varsigma$ znany jest poza LXX, a z kolei termin M $\alpha \delta \beta \alpha \rho i \tau \iota \varsigma$ właściwy jest tylko dla LXXJoz, wydaje się nie mieć odpowiednika w rzeczywistości historycznej i geograficznej czasów hellenistycznych. ${ }^{12}$ Badania nad tym nazewnictwem doprowadziły go także do wniosku, że tłumacz musiał pracować raczej poza Palestyną, gdzie mógł dość „,bezkarnie” używać tych „,pseudo-geograficznych określeń" (pseudogeographische Bezeichnungen). ${ }^{13}$

9 C. G. d e n H e r to g, Jesus. Josue/ Das Buch Josua, s. 611.

10 Tamże.

"Tamie.

12 Tamzie.

13 Tamże. Por. także: $t$ e n ż e, Studien zur grechischen Übersetzung des Buches Josua, Giessen 1996; a na temat geografii Księgi Jozuego jeszcze: t e n ż e, The Geographical Shape of the 
Nie wyjaśnia to jednak, kiedy dokładnie księgę przełożono. C.G. den Hertog zaznacza jednocześnie, że po 198 r. przed Chr., gdy władzę w Palestynie przejęli Seleucydzi, podział na jednostki administracyjne (i tym samym nazewnictwo) uległo zmianie. Dlatego też, w konsekwencji, pierwotny grecki przekład Księgi Jozuego musiał, jak się wydaje, powstać przed 198 r. przed Chr., a tym samym przed czasem kryzysu i prześladowań, jakie przeżywał naród żydowski w czasie panowania Antiocha IV Epifanesa.

Płynie z tego wniosek, że grecka Księga Jozuego powstała nie później niż ok. 200 r. przed Chr., ${ }^{14}$ a ze względu na bliskość z Pięcioksięgiem, raczej w drugiej połowie III w. przed Chr.

\section{Charakter przekladu LXXJoz - niektóre typy zmian}

W porównaniu do innych ksiąg Starego Testamentu w LXX, LXXJoz jest wyjątkowo interesująca, ${ }^{15}$ przez wielu nazywana jest nawet ,jedną z najciekawszych ksiąg Biblii Greckiej”. ${ }^{16}$ Jest tak przede wszystkim dlatego, że znacznie różni się od posiadanego przez nas tekstu hebrajskiego i nie tylko. E. Tov, zajmujący się szeroko tekstem Starego Testamentu, wskazywał, że tekst Księgi Jozuego zawarty w LXX odróżnia się na różne sposoby nie tylko od tekstu ma-

Unconquered Land in Joshua 13:2-5 MT and LXX, w: J. van R u it e n, J. C o r $\mathrm{n}$ e $\mathrm{l}$ i s de $\mathrm{V}$ o s (red.), The Land of Israel in Bible, History, and Theology, Boston-Leiden 2009, s. 51-60.

${ }_{14}$ Por. t e n ż e, Jesus. Josue/ Das Buch Josua, s. 611.

15 Poświęcono jej wiele publikacji, ogólnych i bardziej szczegółowych. Obok cytowanego już opracowania w serii La Bible d'Alexandrie, autorstwa J. Moatti-Fine, wśród najważniejszych należy wymienić: S. H o I m e s, Joshua: The Hebrew and Greek Texts, Cambridge 1914; H.M. O r l i n s k y, The Hebrew Vorlage of the Septuagint of the Book of Joshua, w: G.W. A n d e r s o n, P.A.H. de B o e r, G.R. C a s $\mathrm{t}$ e 11 i n o (red.), Congress Volume - Rome 1968, Supplements to Vetus Testamentum 17, Leiden 1969, s. 187-195; E. T o v, Midrash-Type Exegesis in the LXX of Joshua, Revue Biblique 85/1978, s. 50-61; A.G. A u I d, Textual and Literary Studies in the Book of Joshua, Zeitschrift für die alttestamentliche Wissenschaft 90/1978, s. 412-417; t e nż e, Joshua: the Hebrew and Greek Texts, w: J A. E m e r $t$ o n (red.), Studies in the Historical Books oft he Old Testament, Supplements to Vetus Testamentum 30, Leiden 1979, s. 1-14; D. B a r t h é l e m y, Critique textuelle de l'Ancien Testament, I: Josué, Juges, Ruth, Samuel, Rois, Chroniques, Esdras, Néhémie, Esther, Orbis Biblicus et Orientalis 50/1, FribourgGöttingen 1982; L.J. G r e e n s p o o n, Textual Studies in the Book of Joshua, Harvard Semitic Monographs /Harvard Semitic Museum 28, Atlanta, Georgia 1983; E. T o v, The Growth of the Book of Joshua in the Light of the Evidence of the LXX Translation, w: S. J a p h e t (red.), Studies in the Biblie, Scripta Hierosolymitana 31, Jerozolima 1986, s. 321-339; t e n ż e, Some Sequence Differences between the MT and LXX and their Ramifications for the Literary Criticism of the Bible, Journal of Northwest Semitic Languages 13/1987, s. 151-160.

16 Por. L. J. G r e e n s p o o n, Iesous. To the Reader, s. 174. 
soreckiego (TM), ale także innych wersji starożytnych tej księgi: od syryjskiej Peszitty, aramejskich targumów czy łacińskiej Wulgaty: „W niektórych segmentach LXX [Księgi Jozuego - przyp.] jest [od tych wersji - przyp.] krótsza (możliwie dołącza do niej fragment 4QJosh ${ }^{\text {a }}$, zawierający Joz 8,14-18), w innych segmentach jest dłuższa (por. zwłaszcza zakończenie Jozuego w LXX zmierzające do krótszej, połączonej wersji Ksiąg Jozuego i Sędziów), a jeszcze w innych perykopach znaleźć można inne odróżniające [tekst LXXJoz - uzup.] detale, jak choćby inna pozycja Joz 8,30-35 w TM". ${ }^{17}$ Tov wymienia grecki przekład Księgi Jozuego wśród najbardziej zmienionych i złożonych tekstów LXX, obok m.in. Ksiąg: Jeremiasza, Ezechiela, 1Samuela, czy fragmentów Ksiąg Estery, Daniela, ${ }^{18}$ a nawet wykazuje, że można w LXXJoz odnaleźć elementy midraszowe. ${ }^{19}$

Już na pierwszy rzut oka widać w LXXJoz wspomniane różnice.

Po pierwsze, księga ma ok. 4-5\% mniej tekstu niż hebrajski oryginał. ${ }^{20}$ Takie krótsze wersje ksiąg są w LXX znane (dotyczy to zwłaszcza Ksiąg: Hioba, Jeremiasza czy Przysłów), w każdym jednak przypadku przyczyna obecności tych „braków”21 jest różna. W przypadku LXXJoz są one obecne zwłaszcza tych częściach księgi, które, mówiąc o zdobywaniu i podziale Ziemi Obiecanej, zawierają wiele nazw geograficznych, być może nieznanych tłumaczowi LXX. J. Moatti-Fine wylicza te „braki” dokładnie, nazywając je jednak nie „brakami” LXX, a „dodatkami” TM. ${ }^{22}$ Pierwsze zmiany tego typu pojawiają

17 E. T o v, The Nature of the Large-Scale Differences between the LXX and MT S TV, Compared with Similar Evidence in Other Sources, w: A. S c h e n k e r (red.), The Earliest Text of the Hebrew Bible. The Relationship between the Masoretic Text and the Hebrew Base of the Septuagint Reconsidered, Septuagint and Cognate Studies 52, Atlanta 2003, s. 127.

18 Por. tamie, s. 121-144.

19 E. T o v, Midrash-Type Exegesis in the LXX of Joshua, Revue Biblique 85/1978, s. 50-61.

20 Wyliczenia na podstawie: L J. G r e e n s p o o n, Iesous. To the Reader, s. 175.

${ }^{21}$ Używana czasem przez opracowania naukowe terminologia „braków” i „dodatków” w odniesieniu do jakiejkolwiek wersji tekstu Starego Testamentu, zwłaszcza LXX, jest nieco problematyczna. Należy bowiem wziąć pod uwagę, że terminologia taka nie powinna wskazywać na pierwszeństwo jakiegoś tekstu bądź jego wtórność (co może sugerować użycie terminów „brak” i „dodatek”, względem innego tekstu). Tymczasem to, co jest „brakiem w LXX”, można równie dobrze nazwać „dodatkiem TM" i odwrotnie, w zależności od tego, który z tekstów uznamy za starszy. Wprawdzie tekst hebrajski poprzedzal grecki, jednak do rozstrzygnięcia pozostaje kwestia, czy ten hebrajski tekst, którym dysponujemy, przekazany przez Masoretów, jest tym, który legł u podstaw przekładu LXX. W niniejszym artykule oba terminy używane są technicznie i ukazują stan tekstu LXX w odniesieniu do TM, choć wiemy, że czasem podstawa tekstu LXX jest starsza niż ta, która legła u podstaw TM.

${ }_{22}$ J. M o a t t i - F i n e, La Bible d'Alexandrie. 6: Jésous (Josué), s. 34-36. 
się w LXXJoz już w rozdz. 2 (chodzi o w. 2,15); ${ }^{23}$ potem w rozdz. 6 (ciekawy jest zwłaszcza w. 6,15; zob. poniżej), a później także w innych tekstach: 7,25b; 8,11b.13.15b.16a.20b.26; 10,15; 13,33; 18,10b; w rozdz. 12 (zwł. ww. 14.17.20-21; zob. poniżej); a jeden z najciekawszych pod względem tekstualnym „braków” LXX zawarty jest w rozdz. 20 (ww. 4-6).

Po drugie, LXXJoz ma także sporą liczbę „dodatków”24 LXX względem TM; są one tym ciekawsze, że występują także w kontekście i obok wspomnianych „,braków”. Owo „więcej” LXX względem TM znajduje się np. w: 6,16; 10,12; 13,7b; 15,59a; 16,10; 19,47a;.48a; 21,-36-37; 21,42a-d; 23,5b; 24,3 1a.33a-b. ${ }^{25}$ Najciekawsze zmiany to: 9,2a-f; 19,47a oraz 19,48a; 21,42a-d; a także samo zakończenie księgi w LXX: 24,33a-b (zob. poniżej krótkie uwagi na temat wszystkich).

Po trzecie, złożony charakter tekstu Księgi Jozuego ukazują także inne zmiany LXX względem TM (i innych wersji starożytnych) oraz różnice między samymi manuskryptami greckimi; np. rozdz. 5 ma wprawdzie niemal tę samą liczbę słów w LXX co w TM, ale znaczenie tego tekstu w obu wersjach jest istotnie różne (zwłaszcza ww. 4-6); z kolei rozdz. 15, 18 i 19 mają różną formę zapisu zawartych w nich nazw, tak odmienną, że mówi się dziś o kilku tradycjach greckiego tekstu LXX (zob. poniżej).

Omówienie tylko kilku ze wspomnianych zmian z pewnością obrazuje skalę trudności w pracy z tekstem Księgi Jozuego, a zarazem wskazuje na złożone dzieje powstania i przekazu całości tekstu LXXJoz.

Joz 6,15 jako przykład bogactwa problemów tekstualnych w LXXJoz

Jedna z pierwszych znaczących zmian typu „braki” pojawia się w kontekście opowiadania o zajęciu Jerycha, ${ }^{26}$ gdzie w LXXJoz brakuje ok. 10\% tekstu względem TM. ${ }^{27}$ Owo „mniej” znajdujemy w wersetach: 6,3.4(zupełny brak),6.8.14.15.17.22.

\footnotetext{
23 Tamże, s. 34, przyp. 1.

24 Zob. przyp. 21.

25 Wyliczenie za: J. M o a $\mathrm{t}$ t i - F i n e, La Bible d'Alexandrie. 6: Jésous (Josué), s. 34 (przyp. 1).

${ }_{26} \mathrm{Na}$ temat całości tego tekstu zob. K. B i e b e r s t e i n, Josua - Jordan - Jericho: Archäologie, Geschichte und Teologie der Landnahmeerzählungen Josua 1-6, Orbis Biblicus et Orientalis 143, Fribourg-Göttingen 1995.

${ }^{27}$ L.J. G r e e n s p o o n, lesous. To the Reader, s. 175.
} 
Szczególnie interesujący jest w. 6,15, który dobrze obrazuje poziom komplikacji tekstu Joz, w jego różnych starożytnych wersjach, a także w samym tekście greckim, między poszczególnymi kodeksami i manuskryptami.

W TM werset ten brzmi:

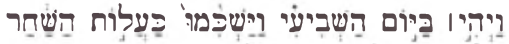

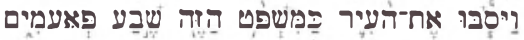

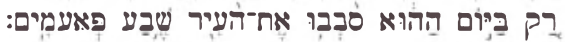

„I stało się, że siódmego dnia wstali wcześnie wraz z zorzą poranną i okrążyli miasto w ustalony sposób siedem razy.

Tylko owego dnia okrążyli miasto siedem razy."

W LXX z kolei (za Kodeksem Watykańskim - B) tekst ten brzmi:

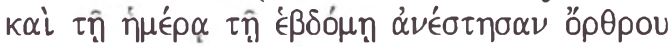

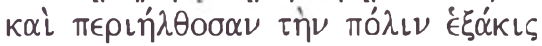

\title{
„A siódmego dnia wstali wcześnie rano
}

i otoczyli miasto sześciokrotnie."

Zmiany dotyczą co najmniej kilku elementów tego wersetu: obok swobody w przekładzie niektórych słów z języka hebrajskiego na

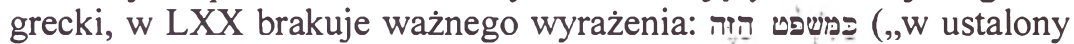
sposób") oraz całej ostatniej części hebrajskiego wersetu (שבכַע פַאעמִים (1), tylko owego dnia okrążyli miasto siedem razy"); a ponadto w miejsce obecnego w pierwszej części zdania hebrajskiego wyrażenia ,siedem razy" (שבֵע פֵַאעמים) pojawia się rzadkie

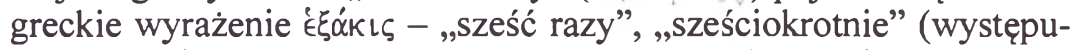
jące w całej LXX tylko trzy razy: tu oraz w $2 \mathrm{Krl} 13,19$ i Hi 5,19).

Pierwsze dwie wspomniane zmiany mają, jak się wydaje, charakter interpretacyjny i poniekąd upraszczają tekst hebrajski, usuwając z niego określenia niekonieczne, mające jakby funkcję dopowiedze-

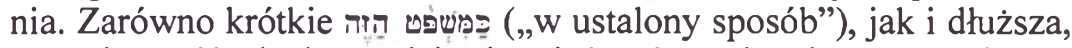
ostatnia część zdania, wydają się mieć wtórny charakter w TM i werset ten w wersji hebrajskiej mógłby się bez nich obejść. Pierwsze krótkie dopowiedzenie jest obecne wprawdzie w innych wersjach starożytnych (np. łacińskiej Vulgacie: sicut dispositum; czy w Targumie:

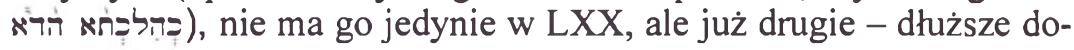


powiedzenie hebrajskie - podobnie jak w LXX ${ }^{28}$ nieobecne jest także w Wulgacie, Targumie i innych wersjach starożytnych, a np. Syrohexapla zaznacza je znakiem asteriska, jako późniejszy dodatek. ${ }^{29}$

To każe zastanowić się nad charakterem i pierwszeństwem tekstów Księgi Jozuego: Czy najpierw był hebrajski w formie zachowanej przez Masoretów (z dopowiedzeniem), czy też, być może, u podstaw greckiego przekładu zawartego w LXX tego wersetu stało inne, starsze od TM hebrajskie Vorlage (nieposiadające owego zdania)? Wówczas tekst ten nie byłby „brakiem” LXX, a „dodatkiem” TM względem hipotetycznego, starszego tekstu hebrajskiego, który stanął u podstaw greckiego przekładu. Dziś coraz powszechniej ukazuje się problem $\mathrm{z}$ tekstem tej księgi właśnie $\mathrm{w}$ ten sposób: już w pierwszej połowie XX w. pojawiły się teorie, zgodnie z którymi tekst LXXJoz reprezentuje starszą, bardziej oryginalną formę tekstu Księgi Jozuego niż ta, która przekazana jest w tekście masoreckim; ${ }^{30}$ kwestię te przedstawiali: S. Holmes (1914), ${ }^{31}$ C. D. Benjamin (1921), ${ }^{32}$ H. M. Orlinsky (1969); ${ }^{33}$ w późniejszych czasach także: A. G. Auld (1976) ${ }^{34}$ E. Tov (1986), ${ }^{35}$ C. G. Den Hertog (1998), ${ }^{36}$ M. N. van der Meer $(2004)^{37} \mathrm{i}$ inni.

${ }^{28}$ Tej części wersetu nie zawierają najważniejsze kodeksy i rękopisy LXX, mają go jedynie dwa minuskułowe manuskrypty greckie, noszące numery 19 i 108, najprawdopodobniej będące pod wplywem hebrajskiego tekstu, takiego, jak w TM; por. F. F i e I d, Origenis Hexaplorum que supresunt; sive veterum interpretum graecorum in totum Vetus Testamentum fragmenta, $\mathrm{t}$. I: Josua, Oxford 1875, s. 348, wraz z przyp. 52.

${ }^{29}$ Zob. tamże.

${ }_{30}$ Zob. J. M o a t $\mathrm{t}$ - - F i n e, La Bible d'Alexandrie. 6: Jésous (Josué), s. 32-38; por. także: C.G. d e n H e r $\mathrm{t}$ o g, Jesus. Josue/ Das Buch Josua, s. 607.

${ }_{31}$ S. H o $1 \mathrm{~m}$ e s, Joshua: The Hebrew and Greek Texts, Cambridge 1914.

${ }^{32}$ C.D. B e $\mathrm{n}$ j a $\mathrm{m}$ i n, Variations Between the Hebrew and Greek Texts of Joshua: Chapters 1-12, Leipzig 1921 .

${ }^{33}$ H.M. O r l i n s k y, The Hebrew Vorlage of the Septuagint of the Book of Joshua, s. 187-195 .

${ }^{34}$ A. G. A u 1 d, Studies in Joshua: Text and Literary Relations, Edinburgh 1976; por. t e nz e, Textual and Literary Studies in the Book of Joshua, Zeitschrift für die alttestamentliche Wissenschaft 90/1978, s. 412-417.

35 E. T o v, The Growth of the Book of Joshua in the Light of the Evidence of the LXX Translation, s. 321-339 (zwł. s. 385-396). 1996.

${ }^{36}$ C.G. d e n H e r $t$ o g, Studien zur griechischen Übersetzung des Buches Josua, Giessen

${ }^{37}$ M.N. V a n d e r M e e r, Formation and Reformulation. The Redaction of the Book of Joshua in the Light of the Oldest Textual Witnesses, Supplements to Vetus Testamentum 102, Leiden 2004. 
Dodatkowym argumentem za takim spojrzeniem na tekst Księgi Jozuego mogą być odkrycia dokonane w Qumran, gdzie odnalezione rękopisy: 4QJosh ${ }^{\mathrm{a}}$ oraz 4QJosh ${ }^{\mathrm{b}}$ (bardzo fragmentaryczne, ale dające pojęcie o różnorodności tekstu tej księgi w starożytności), dostarczyły pewnych danych, pozwalających na stawianie takiej właśnie te$z y{ }^{38} \mathrm{~W}$ obu tekstach zachowały się $\mathrm{w}$ sumie fragmenty następujących Księgi Jozuego:

$-4 Q J_{0 s h}{ }^{\text {( }}$ drugiej połowy II w. lub pierwszej połowy I w. przed Chr.; najstarszy rękopis Księgi Jozuego, jaki posiadamy w jakimkolwiek języku) zawiera fragmenty: Joz 8,34--35; 5,2-7; 6,5-10; 7,12$-17 ; 8,3-14.18$ ? (ostatni werset wątpliwy); 10,2-5.8-11;39

-4 QJosh ${ }^{\mathrm{b}}$ ( połowy I w. przed Chr.) zawiera fragmenty: Joz 2,11-12 ; frag. 3,15-4,3; 17,1-5.11-15.

Wprawdzie w tekstach qumrańskich nie ma wyraźnie zachowanego wersetu 6,15, ale wymieniony fragment, zawierający części innych wersetów rozdz. 6 (a także rozdz. 7 i 8), sugeruje, że mógł istnieć w starożytności tekst hebrajski, odmienny od zachowanego w TM, który mógł stać się podstawą przekładu tej księgi w LXX - znaczna część wersetów tego konkretnego fragmentu zbliżona jest bowiem do tekstu greckiego LXX (takiego, jak w Kodeksie Watykańskim).

Z drugiej strony, mamy w Qumran także ślady tekstu hebrajskiego przypominającego późniejszy TM ${ }^{40}$ Trzeba więc jasno powiedzieć, że w hebrajskich zwojach qumrańskich Księgi Jozuego nie odnaleziono wystarczającej liczby fragmentów, które jednoznacznie określi-

${ }^{38}$ Ich opracowanie krytyczne zob. E.Ch. U r l i c h, 4QJosh ${ }^{a}$, w: E.Ch. Ul r i c h, F. M o or e Cross; S. A. Whit e Craw ford; J. A. D un c a n; P. W. S k e ha n; E. T o v, J.C.B. T r e b o ll e, Qumran Cave 4-LY: Deuteronomy, Joshua, Judges, Kings, Discoveries in the Judaean Desert 14, Londyn 1995, s. 143-152 oraz E. T o v, 4QJosh ${ }^{b}$, w: tamże, s. 153-160; zob. także t e n ż e, $4 Q J^{J}$ sh $^{b}$, w: Z. J. K a p e r a (red.), Intertestamental Essays in Honour of Józef Tadeusz Milik, Qumranica Mogilanensia 6, Kraków 1992, s. 205-212; L.J. G r e e n s p o o n, The Qumran Fragments of Joshua: Which Puzzle are They Part of and Where Do They Fit? w: G.J. B r o o k e, Septuagint, Scrolls and Cognate Writings, Septuagint and Cognate Studies. Society of Biblical Literature 33, Atlanta, Georgia 1992, s. 159-194; A. R o f é, The Editing of the Book of Joshua in the Light of $4 Q J o$ Sh $^{\circ}$, w: G.J. B r o o k e, F. G a r c i a M a r t i n e z, New Qumran Texts and Studies. Proceedings of the First Meeting of the International Organization for Qumran Studies, Paris 1992, Studies on the Texts of the Desert of Judah 15, Leiden 1994, s. 73-80; L. M a z o r, The Septuagint Translation of the Book of Joshua, Bulletin of the International Organization for Septuagint and Cognate Studies 27/1994, s. 29-38. K. B i e b e r s t e i n, Lukian und Theodotion im Josuabuch: Mit einem Beitrag zu den Josuarollen von Hirbet Qumran, Biblische Notizen Beihefte 7, Institut für Biblische Exegese, Monachium 1994.

39 Por. E.Ch. U rl i c h, 4QJosh ${ }^{a}$, s. 147.

40 Por. tamie, s. 153-160. 
łyby stan tekstu księgi w czasach przedchrześcijańskich. Jednak nawet te niewielkie fragmenty hebrajskiego tekstu z Qumran, wskazują na możliwość istnienia różnych form hebrajskich tekstu Księgi Jozuego w starożytności.

Dodatkowo kwestię tekstu Joz 6,15 w LXX komplikuje różnica między poszczególnymi rękopisami greckimi zawierającymi ten werset. Dotyczy to zwłaszcza wspomnianej zmiany hebrajskiego wyra-

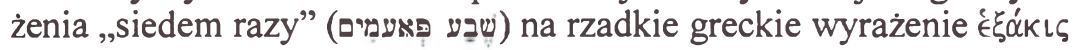
(„sześć razy”, „sześciokrotnie”).

Taka lekcja tego tekstu obecna jest w Kodeksie Watykańskim (B, z IV w. po Chr., najstarszym pośród posiadanych przez nas obecnie kodeksów majuskułowych zawierających pełen tekst LXXJoz ${ }^{4}$ ). Jednak inny ważny kodeks, z przełomu IV i V w. po Chr., Kodeks Aleksandryjski (A), w miejsce wspomnianego rzadkiego wyrażenia $\dot{\epsilon} \xi \hat{\alpha}$

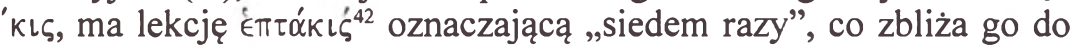
wersji hebrajskiej. Zarówno za jednym, jak i za drugim kodeksem świadczą również niektóre rękopisy minuskułowe. Ciekawe, że lekcję ,siedmiu”, tak jak A (i TM), zachowują także inne wersje starożytne: łacińska Wulgata czy aramejski Targum oraz Syrohexapla ${ }^{43}$ (ta ostatnia być może pod wpływem wersji z kodeksu A).

Choć oba wspomniane kodeksy zgodne są zasadniczo w innych zmianach obecnych w tym wersecie (np. oba nie mają omówionego wcześniej dopowiedzenia z końca wersetu), kwestia tego wyrażenia, a także innych podobnych obecnych w całej księdze zmian, kazała zastanowić się nad posiadanym przez nas tekstem greckim Księgi Jozuego, który także - podobnie, jak hebrajski, ma swoje różne formy.

Już św. Hieronim odnotowywał znane mu różnorodne recenzje tekstu greckiego, oparte na pierwotnym greckim przekładzie LXX, ${ }^{44}$ zwanym Old Greek, którego nie mamy, a który z rozmaitych tek-

${ }^{41}$ Nieco starszy od niego Kodeks Synaicki (S), zawiera jedynie fragmentarycznie zachowane karty Joz, bez rozdz. 6.

${ }^{42}$ Termin $\epsilon \pi \tau \dot{\alpha} \kappa\llcorner\varsigma$ występuje w LXX 28 razy (najczęściej, niemal w połowie przypadków, w Kpl): Rdz 4,24; 33,3; Kpł 4,6.17; 8,11; 14,7.16.27.51; 16,14.19; 25,8; 26,18.24.28; Lb19,4; $1 \mathrm{Krl} 18,43 ; 2 \mathrm{Krl} 4,35 ; 5,10.14 ; 2 \mathrm{Mch} 10,20$; Ps 118,164; Prz 24,16; a w NT w: Mt 18,2ln.; Łk 17,4.

${ }_{43}$ Zob. F. F i e I d, Origenis Hexaplorum, t. I: Josua,, s. 348, wraz z przyp. 51.

44 Te recenzje powstawały w różnych środowiskach. Znamy je z nazw: Hezychiusza, Lukiana i Orygenesa (ta ostatnia, obok LXX, zna jeszcze inne przekłady greckie ksiąg: autorstwa Symmacha, Akwili i Teodocjona; u której podstaw mogła stać znana także i wypracowana najprawdopodobniej w Babilonii recenzja kaige tekstu greckiego). Por. refleksję nad recenzjami greckimi Księgi Jozuego w odniesieniu do tekstu hebrajskiego w: R.G. B o I i n g, 
stów próbujemy odtwarzać. Współczesne badania tekstu LXX, w tym Księgi Jozuego, ukazują całe bogactwo tekstualne greckich rękopisów, odtwarzając zależności między nimi. ${ }^{45}$

W przypadku omawianego wersetu 6,15, różnicę między Kodeksami B i A można tłumaczyć albo ich niezależnym pochodzeniem od różnych tekstów hebrajskich (wówczas u podstaw greckiego tekstu zawartego w A byłaby inna hebrajska wersja tego tekstu niż w przypadku Kodeksu B), albo zależnością - wówczas tekst A można potraktować, jako próbę ujednolicenia tekstu greckiego: z kontekstem następującym (w. 6,16, gdzie pojawia się liczba „siedem” w obu Ko-

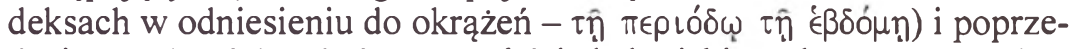
dzającym (w. 6,4, w którym w tekście hebrajskim odnotowany rozkaz Boga zakładał siedmiokrotne otoczenie miasta; wersetu tego, obecnego w TM, jednak nie zawiera ani Kodeks Watykański, ani Aleksandryjski, podobnie jak części w. 6,3 wspominającej okrążanie miasta). W kwestii tego, który z Kodeksów, B czy A, prezentuje bardziej pierwotną wersję przekładu greckiego LXX, bliższą oryginałowi przekładu LXX (Old Greek), zdania znów są podzielone.

Różnice widać już na poziomie wydań krytycznych: niektóre współczesne wydania krytyczne LXXJoz oparte są na tekście Kodeksu A (jak np. A. E. Brooke, N. McLean ${ }^{46}$ ), inne na tekście Kodeksu B (jak np. wydanie A. Rahlfsa ${ }^{47}$ ). Podobnie tłumaczenia LXXJoz: niektóre przyjmują wersję Kodeksu A za bardziej prawdopodobną i taką używają w tekście (tak jest w przekładzie Brentona ${ }^{48}$ i w NETS: ${ }^{49}{ }^{\text {se- }}$ ven times); $z$ kolei Septuaginta Deutsch ${ }^{50}$ oraz seria „La Bible d'Ale-

G.E. W r i g h t, Joshua. A New Translation with Introduction and Commentary, The Anchor Bible 6, Doubleday 1982, s. 108-110.

45 Por. na ten temat oracę doktorską pisaną na Harvardzie, pod przewodnictwem F. Moore Crossa: L.J. G r e e n s p o o n, Studies in the Textual Tradition of the Book of Joshua, 1977; por. R.G. B o I i n g, G.E. W rig h t, Joshua, s. 109.

${ }^{46}$ A.E. B r o o k e, N. M c L e an, The Old Testament in Greek according to the Text of Codex Vaticanus, t. I: Octateuch, cz. 4: Joshua, Judges and Ruth, Cambridge 1917.

47 A. R a h I f s, Septuaginta, Id est Vetus Testamentum Graece iuxta LXX interpretes.

${ }_{48}$ L.C. L. B r e $\mathrm{n}$ t o n, The Septuagint Version of the Old Testament. According to the Vatican Text. Translated into English, with the Principal Various Readings of the Alexandrine Copy and a Table of Comparative Chronology, t. I-II, London 1844.

49 Przeklad LXXJoz w: L.J. G r e e n s p o o n (tłum.), A New English Translation of the Septuagint.

so W. K r a u s, M. K a r r e r i in. (red.), Septuaginta Deutsch. Das friechische Alte Testament in deutscher Übersetzung, Stuttgart 2009, $2010^{2}$. 
xandrie" "\$1 używa w tekście wyrażenia z Kodeksu B (sechsmal, ${ }^{52}$ six fois).

Tego typu zmian i trudności, jak w wersecie 6,15, jest w LXXJoz znacznie więcej.

\section{Pozostałe „braki” w LXXJoz (tekst jasny)}

Kolejne wyraźne i ciekawe z perspektywy tekstualnej „,braki” LXX pojawiają się w rozdz. 12, chodzi dokładnie o wersety 12,14.17.20-21, gdzie nie ma niektórych królów poszczególnych regionów i miast, których, zgodnie z tym tekstem, „zwyciężył Jozue i synowie Izraela po zachodniej stronie Jordanu" (12,7-24).

TM wylicza w całym tym tekście w sumie 31 królów miast, pod-

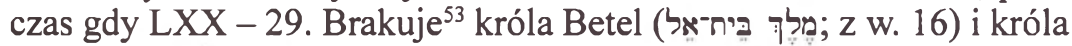
Madonu (מלק מרון; z w. 19). Nie zachowana jest w LXX także specyficzna forma tekstu hebrajskiego, w której po każdym królu miasta pojawia się termin אז, oznaczający ,jeden", jako forma ich wyliczenia. ${ }^{54}$ Ponadto, choć kolejność wszystkich królów w obu wersjach (TM i LXX) jest zasadniczo zachowana, w jednym przypadku jest

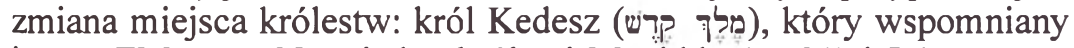
jest w TM w w. 22, między królami Megiddo (w. 21) i Jokneam na Karmelu (w. 22), w LXX jest umieszczony w w. $21,{ }^{55} \mathrm{w}$ formie: $\beta \alpha \sigma \hat{i}$ $\lambda^{\prime} \in \alpha \mathrm{K} \alpha \delta \eta$ s. LXX błędnie odczytała hebr. Kedesz (które było najprawdopodobniej niewielkim miasteczkiem w okolicach Megiddo ${ }^{56}$ ), jako Kadesz, które zindentyfikowała $z$ dużym miastem na północy Palestyny, znanym także dobrze w Egipcie (wspomnianym choćby na świą-

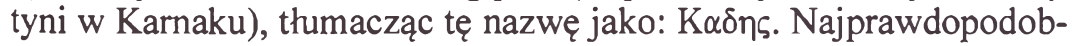
niej z powodu tej błędnej lektury nazwy zmieniono w tekście miejsce tego miasta: skoro odczytano miasto Kedesz jako Kadesz, nie chcia-

s1 Zob. przekład wersetu wraz z komentarzem: J. M o a t t i - F i n e, La Bible d'Alexandrie. 6: Jésous (Josué), s. 125.

\$2 Zaznaczając różnicę między kodeksami w tym tekście w komentarzu: C.G. d e n H e r $\mathrm{t}$ o g, Jesus. Josue/ Das Buch Josua, s. 628.

${ }_{53} \mathrm{~J} . \mathrm{M}$ o a $\mathrm{t} \mathrm{t}$ i - F i n e, La Bible d'Alexandrie konsekwentnie uważa oba przypadki za „dodane” w TM (a nie usunięte z LXX); por. tamże, s. 164; por. także: R.G. B o 1 i n g, G.E. W r i g h t, Joshua, s. 321 .

${ }^{54} \mathrm{Na}$ temat tej formy i jej zmiany w LXX zob. D. B a r $\mathrm{t}$ h é l e m y, Critique textuelle de l'Ancien Testament, I: Josué, Juges, Ruth, Samuel, Rois, Chroniques, Esdras, Néhémie, Esther, s. 23; por. J. M o a t $\mathrm{i}$ - F i n e, La Bible d'Alexandrie. 6: Jésous (Josue), s. 163-164.

ss Zob. tamże, s. 163-164.

36 Por. R.G. B o 1 in g, G.E. W r i g h t, Joshua, s. 329. 
no, by bliskie geograficznie miasta (Jokneam, Megiddo) rozdzielało (jak w TM) miasto, które geograficznie leży dalej (Kadesz).

Z kolei rozważając brak królów Betel i Madonu w omawianym tekście, C. G. den Hertog (powołując się na studium Barthélemy’ego) zwraca uwagę, że pominięcie obu nazw może wiązać się z potrzebą usunięcia obecnych w hebrajskiej wersji dubletów (i chęcią ujednolicenia tekstu). Wskazuje on, że brak Betel może wiązać się z tym, że nazwa ta (dokładnie „króla Betel”) pojawiła się już w omawianym kontekście w w. 12,9,57 zatem jej brak w w. 16 jest może bardziej zrozumiały, jako uniknięcie obecnej w TM powtórki. Z kolei nazwa króla Madonu (מלרן מרון) mogła zostać pomylona z obecnym w w. 20 królem Szimronu Meronu (מלקר שמרון מראון), potraktowana jako dublet (wynikający z pomyłki liter hebrajskich $\urcorner$ i ר) i usunięta, z tych samych powodów. ${ }^{58}$

Co ważne, w kwestii tych konkretnych zmian, zgodne są nie tylko oba wspomniane wcześniej ważne kodeksy (B i A), ale także większość innych rękopisów LXX. ${ }^{59}$ Fakt, że posiadane przez nas ważne greckie rękopisy LXXJoz są ze sobą zasadniczo zgodne, także w greckiej tranksrypcji hebrajskich nazw, może wskazywać, że tekst LXXJoz w tym miejscu mamy zachowany w formie bliskiej tej, jaka mogła wyjść spod pióra tłumacza.

Dodatkową ciekawostką związaną z tym tekstem, jest fakt, że na końcu tej „wyliczanki” królów w wersecie 12,24 w TM pojawia się podsumowanie liczby wyliczonych ,wszystkich królów” (מלבים-

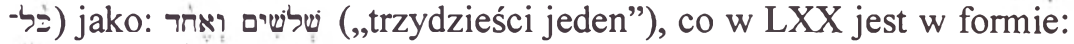

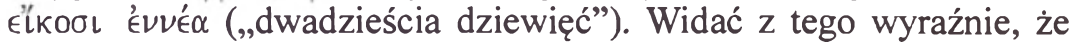
w LXXJoz nie „zgubiono” tych królów przypadkiem na etapie procesu redakcyjnego lub przekazu tekstu, ale w tych wspomnianych zmianach jest obecna świadoma ingerencja thumacza lub redaktorów tekstu. Dlatego w podsumowaniu całości tekstu $(12,24)$ podaje się ich konsekwentnie (jak w tekście) o dwóch mniej. ${ }^{60}$

Inną ważną kwestią dotyczącą tego i innych (bardzo licznych w Księdze Jozuego) tekstów, wyliczających nazwy geograficzne, jest sposób ich przekładu na język grecki oraz ich zapisu, odmiennego na poziomie greckich rękopisów. Nazwy geograficzne funkcjonują czę-

57 C.G. d e n H e r t o g, Jesus. Josue/ Das Buch Josua, s. 638.

s8 Tamze.

59 Por. R.G. B o l in g, G.E. W r i g h t, Joshua, s. 320-321.

60 Więcej na ten temat zob. C.G. de n H e r to g, Jesus. Josue/Das Buch Josua, s. 638. 
sto w różnej transkrypcji, są przekazane błędnie ${ }^{61}$ a czasem zapisane lub odczytane inaczej. Omówienie tego tematu wymagałoby odrębnego studium. ${ }^{62}$

Jednymi z najciekawszych w LXXJoz pod tym względem są duże fragmenty rozdziałów: 15; 18 i 19 (dokładniej: 15,21-62 i 18,22 -19, 45), które różnią się zasadniczo w zapisie nazw miejsc i miejscowości, choćby we wspomnianych już Kodeksach: Watykańskim i Aleksandryjskim. A ponieważ trudno uznać, który z tych zapisów jest bliższy pierwotnemu tekstowi przekładu LXX, niektóre wydania krytyczne (np. A. Rahlfs) umieszczają je obok siebie. ${ }^{63}$

Na przykład wspomniane w rozdz. 18 miasta Beniaminitów, poza Jerychem, mają różną formę w różnych wersjach i rękopisach: wymienione w 18,21 hebr. Bet-Chogla (ביח-זילה) w Kodeksie A zapisane jest jako: $B \eta \theta \alpha \gamma \lambda \alpha$; zaś w Kodeksie B, jako: $B \alpha \iota \theta \in \gamma \lambda \iota \omega$; wspomniane w 18,22 miasto Tsemarim (hebr. צמריר) w Kodeksie A zapisane jest jako: $\Sigma \in \mu \rho \iota \mu$, zaś w B, jako: $\Sigma \alpha \rho \alpha$, a miasto Betel (hebr. ובית־אי

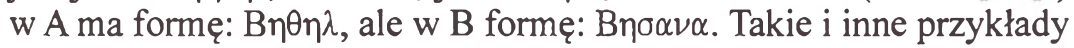
można naleźć we wszystkich wspomnianych rozdziałach.

Różnice te tylko z pozoru są niewielkie i tylko z pozoru nie mają znaczenia. Dla tych, którzy zajmują się geografią Ziemi Świętej, sposób zapisu tych nazw może być, po pierwsze, ciekawym świadectwem ich wymowy w starożytności (różnorodnej, w zależności od środowiska powstania danego kodeksu), a, po drugie, może być świadectwem tego, jak tłumacz i redaktorzy LXX poruszali się w geografii Palestyny (niektóre $\mathrm{z}$ nazw mogły być nieznane autorom i redaktorom LXXJoz, którzy nie żyli w kontekście palestyńskim). Zmiany te mogą czasem wpisać się także w tradycję teologiczną, co w księdze, która mówi o zasiedlaniu i podziale ziemi Kanaan, między po-

${ }^{61} \mathrm{~W}$ omawianym tekście jedną z najciekawszych zmian jest zapis nazwy Laszaron (z wy-

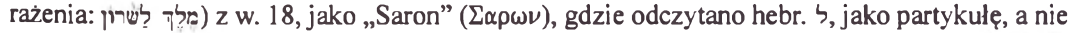

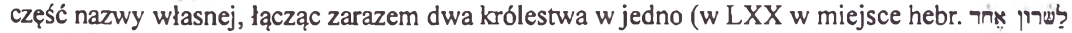

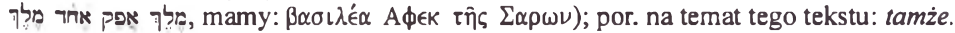

62 Podejmowane są rozmaite studia tej tematyki; zob. np. t e n ż e, The Geographical Shape of the Unconquered Land in Joshua 13:2-5 MT and LXX, s. 51-60.

${ }^{63}$ Podobne przypadki są obecne także w innych księgach LXX: np. w Księdze Sędziów lub Księdze Tobiasza (gdzie z kolei zestawione są razem Kodeksy Watykański i Aleksandyjski równolegle do odmiennego Kodeksu Synaickiego). Podobne różnice dotyczą także Księgi Daniela, gdzie z kolei jest rozbieżnośc między LXX a tekstem historii Zuzanny' przedstawionej w Hexapli Orygenesa, za tekstem Teodocjona; por. wydanie krytyczne A. R a h l f s, Septuaginta, Id est Vetus Testamentum Graece iuxta LXX interpretes. 
szczególne pokolenia, o początkach obecności Izraela w Kanaanie, ma oczywiście kluczowe znaczenie.

Obie wersje (kodeksów B i A), we wspomnianych rozdziałach nawiązują do różnych tradycji nazewnictwa greckiego hebrajskich miejscowości, poświadczonych w różnych źródłach. Jest to tym ciekawsze, że pierwotny przekład grecki od wspomnianych kodeksów dzieli ponad 500 lat. A między nimi a oryginałem hebrajskim (którym nie dysponujemy) różnica lat jest jeszcze większa. To także ukazuje skalę problemów, z jakimi możemy mieć do czynienia przy analizie tekstu Joz.

Inne ciekawe zmiany LXXJoz pojawiają się w rozdz. 20, gdzie mowa jest o miastach ucieczki $(20,1-9)$. W tekście tym pojawia się jeden z najciekawszych „braków” w LXXJoz: 20,4-6. ${ }^{64}$ Jest to pierwsza zmiana, dotycząca nie tylko pojedynczych wyrażeń czy wersetów, ale całego kontekstu; i to nie w tekście wyliczeń, ale w narracji. W tekście liczącym 9 wersetów brakuje w LXXJoz aż trzech: ww. 4-6 (a dokładniej chodzi o całkowity brak ww.4-5 i brak części w. 6). Taki tekst znajduje się w Kodeksie B i w większości ważnych manuskryptów minuskułowych, z kolei Kodekse A ma ten tekst w formie takiej, jak w TM. ${ }^{65}$

Cały kontekst tych „usuniętych" w LXXJoz wersetów opisuje procedurę, zgodnie z którą zabójca może się ukryć w wyliczonych miastach, gdyby był ścigany przez „mściciela krwi” (גאל הַדםם, którym mógł być np. kuzyn mający prawo pomścić zabójstwo, dokonać swoistego samosądu na zabójcy). W LXX brakuje całego fragmentu dotyczącego procedury ucieczki, którą zawiera TM. Próbowano to interpretować na rozmaite sposoby. ${ }^{66}$ Zasadniczo uznaje się, że tekst B (mający „brak”) jest starszy niż tekst A (z dodatkiem). ${ }^{67}$ Wówczas można byłoby w nim widzieć także starszy tekst niż TM. E. Tov z kolei uważa te dwie różne wersje tekstu za przejaw dwóch istniejących jednocześnie w starożytności wersji tekstu o miastach ucieczki. ${ }^{68} \mathrm{Z}$ taką interpretacją wiąże się pytanie: Dlaczego procedura taka została w niektórych wersjach dodana? Może dlatego, że była

${ }^{64} \mathrm{Na}$ jego temat zob. m.in. E. T o v, Textual Criticism of the Hebrew Bible, Minneapolis $2012^{3}$, s. 295-296.

65 R.G. B o l i n g, G.E. W r i g h t, Joshua, s. 473.

66 Więcej na ten temat choćby w: J. M o a t $\mathrm{t}$ - F i n e, La Bible d'Alexandrie. 6: Jésous (Josué), s. 210-213, zwł. s. 212.

${ }^{67}$ Tamie, s. 296.

68 Por. E. T o v, Textual Criticism of the Hebrew Bible, s. 296. 
w niektórych środowiskach praktykowana, a w innych nie? Przykłady tego typu zemsty honorowej były znane w kulturze bliskowschodniej, a nawet w samym Izraelu (por. historię Gedeona z Sdz 8 czy historię opisaną w Sdz 19-20). ${ }^{69}$ Ważne też, że teksty, które jej nie miały, układają się i bez nich w całość (nawet bez tych „usuniętych" ww. 4-6, zdania z ww. 3 i 7 logicznie po sobie następują).

\section{„Dodatki" LXXJoz}

Inny ważny typ zmian w tekście Księgi Jozuego to „dodatki” LXX względem TM (lub inaczej: „braki” TM względem LXX). Każdy $\mathrm{z}$ nich wymaga osobnego studium, w którym należałoby objaśnić różne formy tekstów, ich odniesienia do wersji starożytnych i thumaczeń oraz dostępnych rękopisów. Tu zostaną jedynie wspomniane, ukazując dobitnie całe bogactwo, złożoność i pluralizm tekstów Księgi Jozuego. Każdemu z poniżej wyliczonych fragmentów, można zadać te same pytania: Jak znalazł się w tekście? Od czego zależy dana zmiana? Jak ją interpretować? Czy widzieć w tych „,dodatkach” rolę tłumacza, czy może redaktora (redaktorów) LXX? Czy pojawiły się na etapie powstawania czy przekazu tekstu? Czy są starsze czy młodsze niż TM?

Wydaje się, że odpowiedzią na wszystkie powyższe pytania jest przede wszystkim istnienie wielu form tekstu Księgi Jozuego w starożytności. E. Tov zauważał jednocześnie, że dodatki te niejednokrotnie pozostają pod wpływem tekstów ksiąg sąsiednich (Księgi Sędziów, czy 1 Księgi Królewskiej) lub pod wpływem innych tekstów z samej Księgi Jozuego (zawierają one zdania lub fragmenty wersetów zaczerpnięte $\mathrm{z}$ innych miejsc $w$ księdze, a nawet $\mathrm{z}$ innych ksiąg: zwłaszcza Sędziów, ale i 1 Królewskiej). ${ }^{70}$ Zaznaczał też, że owe dodatki i przeniesienia prezentują na ogół starszą wersję tekstu niż TM.11

Pierwszy „dodatek” w Księdze Jozuego pojawia się już w 6,26a, w historii oblężenia Jerycha, która w większości zawierała „braki” (zob. omówinony w. 6,15). Według E. Tova, tekst ten jest niemal identyczny z $1 \mathrm{Krl}$ 16,34 (co wskazuje na możliwość wzajemnych

${ }^{69}$ R G. B o l i n g, G.E. W r i g h t, Joshua, s. 476.

70 E. T o v, Textual Criticism of the Hebrew Bible, s. 297.

7 Tamże. 
wpływów tych tekstów na siebie ${ }^{72}$ ). Z $1 \mathrm{Krl}$ związany jest także, według niego, dodatek w w. 16,10a.

Kolejny, nieco większy, „dodatek” to w. 9,2a-f, który można uznać za tzw. dodatek pozorny - czyli przeniesienie fragmentu tekstu z jednego na inne miejsce księgi. Tu mamy do czynienia $z$ fragmentem opowieści o budowie przez Jozuego ołtarza dla Pana na górze Ebal ${ }^{73}$ (w TM zawartej w Joz 8,30).

Kolejne „dodatki” w LXXJoz to dwa krótkie wersety w kontekście rozdz. 19: chodzi o ww. 47a oraz 48a. Oba te blisko siebie położone wersety są z kolei fragmentami Księgi Sędziów: pierwszy to fragment Sdz 1,34-35, drugi zaś to fragment Sdz 1,35. Rozważanie wzajemnej zależności między wspomnianymi księgami pozostaje jednym z ciekawszych zagadnień, jakie stoją przed badaniami tekstualnymi tych ksiąg.

Kolejny ciekawy dodatek LXXJoz znajduje się w 21,42a-d, gdzie po tekście dotyczącym miast Merarytów, pojawia się dodatek mówiący o mieście dla samego Jozuego. Tekst ten opowiada o wątku miasta należącego do Jozuego, które jako wódz, otrzymał, sam odbudował, gdzie zamieszkał i gdzie złożył krzemienie obrzezania. Miasto to leżało w górach Efraima i nazywało się po grecku $\Theta \alpha \mu \nu \alpha \sigma \alpha \rho \alpha \chi$ (to nic innego jak wspominana w TM, w 19,50 i 24,30, w kontekście śmierci Jozuego, hebr. חרית - Timnat-Serach).

Sam początek tego „dodatku”, mówiący o dziale Jozuego, jest znów dodatkiem pozornym: został bowiem przeniesiony tu $\mathrm{z}$ innego miejsca Księgi Jozuego: dokładniej z rozdz. 19,49-50. Jednak druga część, mówiąca o kamieniach obrzezania, jest nieznana tradycji masoreckiej. Co ciekawe, ten wątek podejmuje w jednej z homilii do Księgi Jozuego Orygenes ${ }^{74}$ (co pokazuje, że opierał się na greckim tekście księgi). Czyżby usunięto w TM wątek o powtórnym obrzezaniu dokonywanym przez Jozuego? Czy też dodano go do tekstu LXX? I dlaczego? Na ten temat, a także na temat następnego dodat$\mathrm{ku}$, odrębne studium podjął A. Rofé. ${ }^{75}$

72 Tamże.

${ }_{73}$ W tekście LXX nazwa tej góry brzmi: Gaibal; znów zwraca uwagę podwójny sposób zapisu nazwy i jego transkrypcja.

${ }_{74}$ Zob. J. M o a t $t$ i - F i n e, La Bible d'Alexandrie. 6: Jésous (Josue), s. 219.

75 A. R o f é, The End of the Book of Joshua according to the Septuagint, Henoch 4/1982, s. 17-36, zwl. s. 34 . 
Ostatnim - i najciekawszym z punktu widzenia teologicznego dodatkiem w LXXJoz jest sama końcówka Księgi Jozuego w LXX: 24,33a-b. Po opisie śmierci Jozuego, syna Nuna (24,19-31; przypominającej śmierć Mojżesza na końcu Księgi Powtórzonego Prawa), mowa jest o kościach Józefa, które pochowano w Sychem, a także o śmierci Eleazara, syna Aarona (ww. 32-33; za LXX). Po tych wątkach następuje dodatek, którego nie posiada ani TM, ani inne wersje starożytne.

Tekst ten jest lekcją oryginalną LXX, tym ciekawszą dla badaczy tego tekstu.

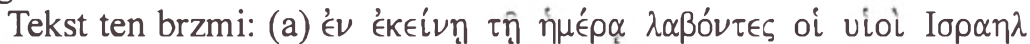

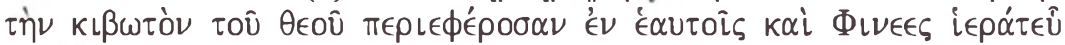

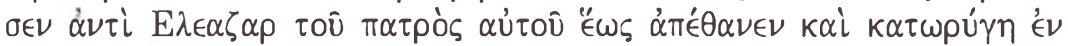

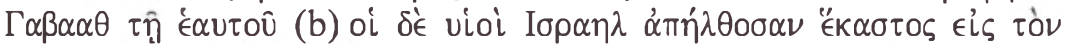

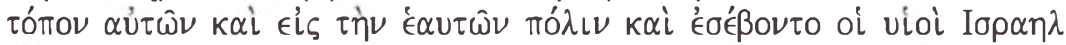

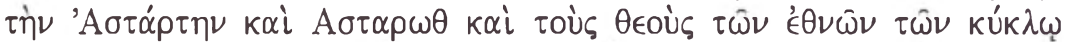

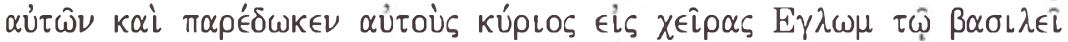

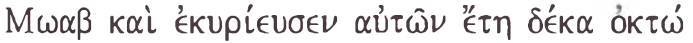

W przekładzie za LXX: „(a) W owym czasie synowie Izraela zabrali arkę Boga i przenieśli ją do siebie. Urząd kapłana pełnił wtedy po Eleazarze, swoim ojcu, Finees, dopóki nie umarł. Pogrzebany został w Gabaathu, swojej własności. (b) Synowie Izraela rozeszli się, każdy do swojej siedziby i do swojego miasta. Ponieważ potem synowie Izraela zaczęli czcić Astarte, Astaroth i innych bogów okolicznych plemion, Pan wydał ich w ręce Edoma, króla Moabu. Panował on nad nimi przez osiemnaście lat".

Dodatek LXX na końcu ksiegi burzy koncepcję, obecną w TM, zgodnie z którą Księga Jozuego kończy się, analogicznie do zakończenia Pięcioksięgu, śmiercią głównego bohatera: ${ }^{76}$ na końcu Pięcioksięgu opisana jest śmierć Mojżesza; na końcu hebrajskiej Księgi Jozuego - opisana jest śmierć Jozuego, jego następcy. Dodatek LXX, który następuje dalej, jest dość trudno zrozumiały w kontekście chwalebnej historii Jozuego, tak jak jest ona przedstawiona w TM. Tekst ten mówi bowiem o grzechach Izraela, który zaczął czcić obcych bogów. Zdaniem E. Tova, to właśnie ta dłuższa forma tekstu jest pierwotniejsza, ${ }^{77}$ a A. Rofé ukazuje, że istniała nawet hebrajska forma

${ }^{76}$ J. M o a t $t$ i - F i n e, La Bible d'Alexandrie. 6: Jésous (Josué), s. 239.

77 Por. E. T o v, Textual Criticism of the Hebrew Bible, s. 297-298. 
tego tekstu (niezachowana dziś w świadkach tekstu, ale łatwa do retranslacji z greckiej wersji zachowanej w $\mathrm{LXX}^{78}$ ), która została potem usunięta, z powodów ideologicznych. ${ }^{79}$ Ważne też, że ten tekst, przechowany w tradycji LXX, w swoisty sposób wprowadza do dalszej historii narodu wybranego, opisanej w Księdze Sędziów. ${ }^{80}$

Takie ujęcie sprawia, że dodatek z końca księgi staje się także ważną wskazówką do odczytywania położenia tej księgi w obu kanonach (hebrajskim i greckim). ${ }^{81} \mathrm{~W}$ obu Księga Jozuego leży bezpośrednio po Pięcioksięgu i do niego nawiązuje (tak że niektórzy uważają, iż tworzy z nim nawet tzw. Hexateuch), jednak przypisana jest do różnych części: w Biblii Hebrajskiej stanowi część tzw. Proroków Pierwszych (hebr. נביאים ראשנגים), w LXX - rozpoczyna księgi historyczne

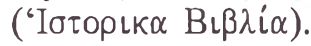

\section{Pierwotny tekst grecki Księgi Jozuego (Old Greek). Wydania krytyczne LXXJoz}

Wszystkie wyliczone zmiany, i inne nie wspomniane (np. zmiana kolejności rozdziałów 8 i 9 w TM i LXX ${ }^{82}$ ), pokazują skalę problemów tekstualnych, z którymi musi się zmierzyć ten, kto chce zbadać zarówno grecki jak i hebrajski tekst Księgi Jozuego. Kwestie tekstualne w przypadku tej księgi pozostają jednymi z bardziej złożonych w całej LXX i Biblii Hebrajskiej.

W kontekście wszystkich omówionych problemów wciąż aktualne i ważne pozostaje pytanie: Czy w ogóle możliwe jest dotarcie do pierwotnego tekstu greckiego Księgi Jozuego, który wyszedł spod pióra tłumacza LXX? Oczywiste jest, że tylko taki tekst mógłby być przedmiotem analiz porównawczych między tekstem hebrajskim, a aleksandryjskim przekładem. Na podstawie takiego tekstu dopiero moglibyśmy w sposób pewny odtworzyć tendencje teologiczne tłumacza

${ }^{78}$ A. R o f é, The End of the Book of Joshua according to the Septuagint, s. 17-36; por. E. T o v, Textual Criticism of the Hebrew Bible, s. 298.

79 A. R o f é, The End of the Book of Joshua according to the Septuagint, s. 17-36; por. E. T o v, Textual Criticism of the Hebrew Bible, s. 297-298.

${ }^{80} \mathrm{~J} . \mathrm{M}$ o a t $\mathrm{t}$ i - F i n e, La Bible d'Alexandrie. 6: Jésous (Josué), s. 239 ; por. taki pogląd w: O. M u n n i ch, Le texte de la Septante, w: G. D o r i v a l, M. H a r I, O. M u n n i c h, La Bible Grecque des Septante. Du judaïsme hellénistique au christianisme ancien, Initiations au christianisme ancien, Paris 1988, s. 175 (wraz z bibliografią).

${ }^{81}$ Por. J. M o a t t i - F i n e, La Bible d'Alexandrie. 6: Jésous (Josue), s. 19-21.

82 Zob. na ich temat: E. T o v, Textual Criticism of the Hebrew Bible, s. 298-299. 
aleksandryjskiego, śledzić rozwój jego myśli i wiary. Tymczasem w dotarciu do niego nie pomagają ani posiadane przez nas rękopisy LXXJoz, z których najstarsze pochodzą z okresu kilkuset lat po powstaniu oryginału (najstarszy niepełny grecki tekst Księgi Jozuego zawarty jest na papirusie Oxyrynhos 1168, obecnie w Princeton, pochodzi dopiero z ok. 350 r. po Chr. i zawiera fragment rozdz. 4,23$-5,1^{83}$ greckiej księgi; zaś najstarszy pełny tekst księgi zachowany jest we wspomnianym majuskułowym Kodeksie Watykańskim - B, pochodzącym również z IV w. po Chr. i Kodeksie Aleksandryjskim, tylko nieco młodszym), ${ }^{84}$ ani złożoność form tekstu księgi, jaka dociera do nas w źródłach greckich i hebrajskich (także tych najstarszych, odnalezionych w Qumran), jak i innych wersjach starożytnych. ${ }^{85}$

To każe zwrócić uwagę już nie tylko na historię powstania przekładu tekstu LXX, jego Vorlage, genezę i jego charakter, ale także skłania do refleksji nad złożonością dziejów przekazu Księgi Jozuego w okresie od jej powstania, do najstarszych manuskryptów oraz nad złożonością tekstu tej księgi, która w przypadku LXXJoz, stawia przed egzegetami wciąż nowe pytania i wyzwania.

Bardzo często w obecnych badaniach nad tekstem Księgi Jozuego, zamiast prób docierania do oryginalnego tekstu thumacza LXX, proponuje się, by odczytywać te rozmaite złożoności, recenzje i różnice jako swoistą, równolegle istniejącą, polifonię tekstów księgi. Obecnie coraz rzadziej podejmuje się próby wskazania rękopisu najbardziej bliskiego oryginałowi (dotyczy to zarówno tekstu hebrajskiego, jak i greckiego), ale raczej ukazuje tekst w jego bogatej złożoności.

Także wydania krytyczne tekstu greckiego LXXJoz uwzględniające i zaznaczające te rozmaite różnice nie pozostają jednolite. Do najważniejszych z wydań krytycznych LXXJoz należą:

${ }^{83}$ C.G. d e n H e r $t$ o g, Jesus. Josue/ Das Buch Josua, s. 607.

${ }^{84}$ Pośród innych ważnych rękopisów majuskułowych tekst LXXJoz zawierają jeszcze Kodeks Synaicki (S), który jednak zawiera jedynie fragmentarycznie zachowane karty zawierające rozdz. 12-13 i 14 (dokładniej fragmenty: 12,2-13,10 oraz 13,11-14,4). Na temat tych rękopisów zob. tamże, s. 607; por. także odpowiednie karty Kodeksu Synaickiego, udostępnione w 2011 r. i prezentowane na stronie internetowej: www.codexsinaiticus.org (dostęp: 1 X 2014); zob. także jego faksimile: Codex Sinaiticus. A facsimile edition, The British Library-Hendrickson, London-Peabody 2010. Na temat projektu digitalizacji i samego tekstu Kodeksu zob. także: D.C. P a r k e r, Codex Sinaiticus: the Story of the World's Oldest Bible, London-Peabody 2010.

${ }^{85}$ Por. refleksje na ten temat: R G. B o 1 i n g, G.E. W r i g h t, Joshua, s. 108-110. 
- A. E. Brook-N. McLean, The Old Testament in Greek according to the Text of Codex Vaticanus, t. I: Octateuch, cz. 4: Joshua, Judges and Ruth, Cambridge 1917;

- M. L. Margolis, The Book of Joshua in Greek, Paryż 1931-1938;

- A. Rahlfs, Septuaginta, Id est Vetus Testamentum Graece iuxta LXX interpretes, Stuttgart 1935, 1965';

- E. Tov (red.), Max L. Margolis, The Book of Joshua in Greek, cz. V: Joshua 19,39-24,33, Philadelphia 1992;

- elementy krytycznych wydań zawierają także wspomniane wcześniej opracowania tekstu Księgi Jozuego. ${ }^{86}$

Studium tego tekstu greckiego Księgi Jozuego nie ułatwia fakt, że nie mamy jeszcze wydania krytycznego greckiego tekstu Księgi Jozuego w serii z Göttingen. Od kilkunastu lat jest ona w ciągłym opracowaniu i wciąż niedostępna. Być może fakt ten można wytłumaczyć złożonością tekstualną księgi w połączeniu z wieloma problemami krytycznymi jej dotyczącymi.

A przecież najlepsze poznanie tekstu Księgi Jozuego, nawet w jej wielowymiarowości tekstualnej, musi być priorytetem, tym bardziej że rzutuje także na interpretację żydowską tej księgi jeszcze w czasach przedchrześcijańskich, a także na teologię pierwszych wieków Kościoła, która uznawała Księgę Jozuego za niezwykle ważną, a w głównym jej bohaterze, który po grecku nosi imię Jezus ('I†ooûs), widziała ważny typ Chrystusa w Starym Testamencie. ${ }^{87}$

Barbara STRZAEKOWSKA

${ }^{86}$ Por. ich wyliczenie także w: E. T o v, Textual Criticism of the Hebrew Bible, s. 294-295.

${ }^{87} \mathrm{Na}$ temat tego imienia, zob. J. M o a $\mathrm{t} \mathrm{t} \mathrm{i}-\mathrm{F}$ i n e La Bible d'Alexandrie. 6: Jésous (Josué), s. 18, 25-29. 